JAMES SLOTTA

University of Texas at Austin

\title{
Can the subaltern listen?
}

\section{Self-determination and the provisioning of expertise in Papua New Guinea}

\begin{abstract}
A B $\mathbf{S} \quad \mathbf{T}$ R A C $\mathbf{T}$
Voice is a major concern in contemporary liberal-democratic politics, one that stresses the political importance of speaking ("giving voice," "speaking up"). But in the Yopno valley of Papua New Guinea, where NGO and government projects are expanding, people's sense that they are losing control of their future has led them to worry about their capacity to listen, not their capacity to speak. In largely acephalous villages, people's self-determination seems particularly threatened by their ignorance of the true nature of their own actions. From a perspective in which the antecedents and the consequences of action are deeply unclear-a perspective stressed in the provisioning of expertise prevalent in political discourse-self-determination hinges on listening and gaining the understanding needed to shape one's future. [political communication, expertise, self-determination, voice, listening, Papua New Guinea, Melanesia]
\end{abstract}

Long tingting bilong planti saveman bilong demokratik politiks na arapela manmeri tu, toktok em $\mathrm{i}$ as bilong paua bilong ol manmeri. Tasol, ol manmeri i stap long Yopno veli, wanpela hap bilong Papua Niugini, ol i no save wari tumas long tokaut. Maski gavman na NGO i laik wokim planti samting long hap, ol i no tingting planti long toktok tumas. Tasol, ol i wari planti long harim: ol inap long harim toktok na i stap fri o nogat? Long hap, ol lida bilong ples na gavman, ol i nogat paua long bosim ol manmeri bilong ples. Ol manmeri i ken bihainim laik bilong ol. Tasol, ol i wari olsem, nogut tingting bilong mipela i paul na mipela i no save gut long wei bilong kamapim ol samting mipela laik kamapim. Ol i lukim olsem paul tingting na nogat save em i wanpela kain kalabus. Olsem na, ol save tok olsem, ol mas harim gut toktok bilong ol saveman na kisim save. Dispela em i rot bilong bihainim tru laik bilong ol na kamapim samting ol $i$ laik kamapim bihain. [toktok, saveman, bihainim laik, tokaut, harim toktok, kisim save, Papua Niugini]

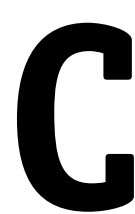

an the subaltern listen? I raise this question because it throws into relief the way that political power has been yoked to the act of speaking in contemporary liberal-democratic politics. This connection is particularly evident in the attention scholars, activists, and others give to "voice": giving voice, listening to the voiceless, speaking up, speaking back, and the like. Why is it that speaking, rather than listening, is held up as an indispensable means of securing a measure of power and self-determination? I came to this question during my research in the Yopno valley of Papua New Guinea, where people's sense that they are losing control of their future in the face of expanding NGO and government projects has given rise to concerns less about their ability to speak than about their ability to listen. This emphasis on listening as a means of advancing one's self-determination needs unraveling, particularly in view of its divergence from more familiar concerns about speaking and voice.

In her well-known essay "Can the Subaltern Speak?," Gayatri Spivak (1988) argues that the inability of the subaltern woman to represent herself amid the dominant discourses of colonizers and the elite-her inability to speak as a political subject-is part and parcel of her subjugation. As Spivak says elsewhere, "If the subaltern can speak then, thank God, the subaltern is not a subaltern any more" $(1989,283)$. Though Spivak's essay is, in part, a critique of the subaltern studies' project of giving voice to the subaltern subject, it shares with this project an emphasis on the political significance of speaking and, in particular, the role of speech in enabling some measure of self-determination. In David Ludden's words, the project of subaltern studies is one in which "historians and post-colonial critics stand together against colonial modernity to secure a better future for subaltern peoples, learning to hear them, allowing them to speak, talking back to powers that marginalise them, documenting their past" $(2002,20)$.

These expressions-"allowing them to speak," "talking back to," "learning to hear"-are a familiar part of a contemporary politics of voice. In this politics, to be silenced or to go unheard is to be denied a measure of participation and power that all citizens or human beings are entitled to. Having a voice-speaking and being heard-is an indispensable mode of achieving and exercising self-determination in this

AMERICAN ETHNOLOGIST, Vol. 44, No. 2, pp. 328-340, ISSN 0094-0496, online ISSN 1548-1425. (C) 2017 by the American Anthropological Association. All rights reserved. DOI: $10.1111 /$ amet.12482 
democratic perspective on political legitimacy. Listening, in contrast, is not; indeed, listening is often framed in the politics of voice as an act of deference or even submission. So, for instance, calls to redress inequalities and past injustices often involve demands to invert the communicative roles of speaker and listener- "for previously voiceless members of society to gain voice, some who have monopolized or controlled speech may need to be silent and learn to listen" (Rakow and Wackwitz 2004, 95). Speaking and listening are both necessary aspects of the politics of voice, but political power and self-determination flow from speech.

Given the prevalence of this framework as a part of a globalizing, democratic perspective on political communication (Kunreuther 2014), to be concerned about listening, as many in the Yopno valley are, might suggest that people there view themselves as powerless, that they see their role as one of deference to the voices of others. But Yopno concerns about listening reflect a different sensibility about where power resides in communication and the role of communication in realizing self-determination.

Let me illustrate with an example. There is, on the north coast of Papua New Guinea, not too far from the Yopno valley, a nickel-cobalt refinery built by a Chinese corporation (Leach 2011). Among people in the Yopno valley, the story of this plant is often presented as a cautionary tale of the misery that mining-related development can bring. At the site of the plant, locals have been displaced from their land, had their gardens and fishery polluted, and been subject to the violence of workers. But interestingly, Yopno people I have talked about this with rarely criticize the corporation that runs it or the Papua New Guinean government, which pushed for the project. As the tale is often told, responsibility for the misery of the locals lies in the hands of the locals themselves: they did not understand what their agreement to this project would entail, thinking only of the money and jobs they would receive. This is a highly partial version of how the project came about; in fact, local residents protested the refinery and undertook legal efforts to prevent it (McLeod 2013).

But the Yopno version of this story is true to a local communicative sensibility, one that stresses both the power of listeners and the political significance of listening. In the words of one man from the Yopno valley working with a conservation NGO: "You want to say yes to some big mining exploration effort? Be careful. They'll give you 40 pages [of a contractual agreement] to read and sign. We're Papua New Guineans. We won't finish those 40 pages. [...] We'll thrill at the prospect of money and say, 'OK, I'll sign.'” The ability of people in the Yopno valley to listen well—or in this case, to read carefully—is often the focus of concerns about maintaining control over their future. And to ensure that people have the wherewithal to listen well in the future and preserve control over their land, they are enjoined by people to "listen up" to the informed advice offered by experts like this conservation worker.

"Listening well" is a skill emphasized in Yopno social life as the means to become a "knowing human being" (Wassmann 2016, 95). Building on this connection between listening and knowledge, I contend that it is a local epistemology - one that stresses the opacity of reality to untrained human understanding-that renders listening a politically significant mode of fostering self-determination. In largely acephalous Yopno villages, people do not often experience their self-determination being impinged on by community leaders or the state. Rather, villagers see their self-determination as particularly threatened by their own ignorance, specifically their failure to understand the true nature of their own actions. From a perspective in which the possibilities, the antecedents, and the consequences of action are deeply unclear-a perspective stressed in the provisioning of expert knowledge prevalent in Yopno discourse-self-determination hinges on listening and gaining the expertise to truly shape one's own future.

\section{Sovereign speakers and willful listeners}

The political significance of speaking is embedded in a range of contemporary political theories that emphasize participation and inclusion as central elements legitimizing liberal-democratic governance. Although theories of communicative ethics, deliberative democracy, agonistic pluralism, communicative democracy, and the like differ on the kinds of speech that sustain and legitimize a democratic polity, they all place speech at the center of liberaldemocratic politics (e.g., Chambers 2003; Habermas 1996; Mansbridge 1990; Mouffe 2000; Young 2000). Discourse ethics, for instance, rests on the language game of argumentation, in which the legitimate force in politics is the "unforced force of the better argument," according to Jürgen Habermas $(1996,306)$. Which is to say, legitimate power lies in the hands of speakers and in speech of a certain sort.

The emphasis on speech and speaking grows out of a view dating back at least to Jean-Jacques Rousseau, who regarded democratic legitimacy as resting on the state's capacity to secure the self-sovereignty of "the people." Self-sovereignty in his view is realized when the laws and policies enacted by the state reflect the "voice of the people": "obedience to the law one has prescribed for oneself is liberty" (Rousseau 1987, 151). In Habermas's formulation of democratic self-sovereignty, the communicative roles are explicitly delineated: "The idea of self-legislation by citizens . . . requires that those subject to law as its addressees can at the same time understand themselves as authors of law" (1996, 120).

This mode of self-determination is built around a "sovereign speaker"-to adapt one of Judith Butler's (1997) 
expressions-who issues binding laws backed by a variety of means of coercion. The communicative condition that legitimizes this speaker's power is, as Habermas says, that all who are subject to the law as addressees must themselves be sovereign speakers of the law. As speakers of the law, the people exercise power as the sovereign; as addressees, they submit to the law as citizens.

The politics of voice draws on this legitimacyconferring, democratic model of sovereign speakerhood to challenge the legitimacy of political arrangements in which those who are addressees of the law and affected by government policy are prevented from inhabiting the role of a sovereign speaker who shapes law and policy. The politics of voice, then, associates self-determination with speaking and submission with listening, associations that are central to a democratic model of self-sovereignty. ${ }^{1}$

In contrast, there is little to indicate that sovereignty is exercised through speech in politics as practiced in the Yopno valley. Located in the Finisterre Range on the border of Morobe and Madang provinces, the Yopno valley is home to some 8,000 people living in 25 villages. Almost all inhabitants of the valley are subsistence horticulturalists, supplying their own food, shelter, and firewood from land they own as customary landowners (Keck 2005; Kocher Schmid 1991; Wassmann 2016).

Though every village has people who are recognized as community leaders-the heads of clans, school-board members, and people who hold positions in the Lutheran Church - these people, almost all men, have relatively few means to coerce community members to act. They rely primarily on talk in their efforts to direct the collective activities of villages: for example, hosting church and educational events, building schools and coffee-drying facilities, and collecting gifts and organizing ceremonial dance participants for festivities held in other villages.

And as in many egalitarian-minded communities, people in the Yopno valley often appear to be "all talk and no action" (e.g., Brison 1989; Kulick 1992; Myers 1986). Community leaders typically hold lengthy discussions in which villagers work to achieve agreement on a course of action. But when community members feel they have not been consulted or have not collectively agreed on a course of action, they simply ignore the instructions of community leaders, often grumbling that they are not their laborers (Y: oman amin; TP: wokboi) or slaves (TP: slev). ${ }^{2}$ In Yopno villages, where community members value their self-determination and have the means to exercise it, creating a unity of wills is an indispensable yet onerous part of leadership (Slotta 2015).

In Nian village, the month leading up to the start of the school year in February 2008 was filled with efforts to encourage the community to prepare the school: to build a new classroom and a house for a teacher to live in. The efforts kicked off on January 6 with a large event in which regional education leaders and teachers spoke to the community about the importance of education. Nonetheless, the day after the inspirational speeches-the day of the week designated for community work projects-virtually no one showed up at the school to do the work. I spoke later in the week with the school-board chairman, who explained that no one showed up because he had not brought about consensus (TP: kamapim wanbel). He said he was planning to hold a meeting to consult with community members before the next week's community workday. But when the next week rolled around, few showed up to work once again.

The preparations for the start of the school year had coincided with the annual harvest of pandanus nuts, which led much of the community to spend a month or more living in their forest houses away from the village. Calls for the community to gather and work on the school continued whenever people gathered-at semiweekly village markets, church services, and another education awareness event held February 3 to coincide with the start of the school year.

Given all this talk and so little action, it is perhaps not surprising that a common refrain among community leaders urging fellow villagers to act is the very futility of their efforts. In the following speech from February 16, over a month into the process and about a week after the delayed start of school, Topa, a community leader in Nian, struggles to continue pushing people to complete work on the local elementary school:

\section{We leaders are few.}

We are a small group, those of us speaking out about the school.

We talk about this, and I see you don't respect us.

Very sorry, but I feel it is really hard to speak.

You all are a lot of people, and I'm just one person speaking, so you all won't listen to me. ${ }^{3}$

In a political environment in which people regard one another as willful and often unmanageable-where they are said to "follow their hearts" (Y: but yol-) and not the instructions of others (Y: gen yol-, "follow talk, follow instructions")-there is little indication that power resides in speech. ${ }^{4}$ It is common, as in this instance, for speech to have no effect at all. Instead, the acephalous character of political relations among those in Yopno villages spotlights the agency and power of listeners to shape the outcome of communicative encounters. Speakers are left to urge listeners to heed their words, and they expend much effort tailoring their appeals to elicit the involvement of listeners, recognizing that the effectiveness of speech lies in large measure in the hands of listeners and what they do with speech. In Joel Robbins's felicitous phrase, speakers are left to "run-it-up-the-flag-pole-and-see-who-salutes" 
(2001, 906; for more on the significant role of listeners in Melanesian ideologies of communication, see Kulick 1992; Rodman 1991; Schieffelin 1990).

Where people do not have the capacity to act as sovereign speakers, speech is neither a conspicuous mode of exerting power nor an obvious means to foster one's self-determination. Rather, the listener stands out as a participant whose will must be reckoned with. And it is with respect to the listener and the value of listening that an interesting mode of politics plays out, one that centers on the provisioning of expertise.

\section{Instruction, self-determination, and the needs of listeners}

Though speech is often ineffective in Yopno village politics, neither leaders nor community members consider speaking inevitably pointless or ineffective. Community leaders continue to talk about projects, and they spend a great deal of time strategizing about how to influence listeners (Slotta 2015).

What, then, does political discourse look like? First, though people routinely disregard the instructions, orders, and rules (Y: nuwa gen) issued by community, clan, and church leaders, they often seek out these same people for instruction on esoteric matters such as migration histories, genealogies, magic, forest spirits, and the ways of the Christian god. As in many other parts of Melanesia (Lindstrom 1984), positions of leadership in Yopno villages rest on the control of and the ability to communicate special knowledges, which other people seek out.

For instance, Kabwum, a middle-aged man living in Nian village, spent well over a year trying to get clan leaders to provide him the esoteric knowledge he needed to interact with a spirit that lived on land he was claiming as his own. His family had fled Nian during a feud two generations earlier, and he was raised in a neighboring valley. He lived for a period in urban Papua New Guinea when his father took up work as a medical assistant, but after running into trouble as a member of an urban gang he returned to Nian, his homeland. Interacting with the spirit that lived on his father's land would help him secure control over this land and gain other benefits that powerful forest spirits provide. But as he recounted to me, in tears, not one of his clan-mates would reveal knowledge of this spirit to him. He eventually left the village.

While Yopno people are loath to be addressed with orders and instructions-which, in effect, render them "slaves"-many, like Kabwum, seek out instruction on esoteric matters to gain greater control of their future. And community leaders tailor their speeches to their audiences' interest in acquiring specialized knowledge. Their public announcements have a striking didactic quality; instructions are continually interwoven with instruction. One didactic feature in particular illuminates the connection between listening, knowledge, and self-determination: the expert redescription of action. The following is a portion of another speech concerning the school given by Nian village's evangelist-a Lutheran church worker from a different village in the Yopno valley-two weeks before Topa's frustrated speech above:

It's the work at the school that I'm talking about.

Let's listen and complete it.

Do you think that these children of ours are going to amount to something?

If you think so, then you should worry about our children.

Tomorrow, they will be-you don't know-

Tomorrow there will only be educated people.

After our time now, there will only be educated people.

Or, if you want the children of Nian to be the ones who wash the clothes of people from other villages,

all right, you can keep doing things this way [i.e., continue to not prepare the school for the new school year].

[...]

Tomorrow, there will only be educated people.

We don't want some of us to end up pitiful and ignorant.

You all aren't motivated by this sort of talk.

You aren't moved. Let's change. That's it. Let's tend to the school.

The evangelist's speech is a mix of instruction (e.g., about what the future holds) and instructions (e.g., about what people should do, given what the future holds). His instruction concerns the relation of means to ends, a recurring feature of didactic political discourse. The conditional if-then construction used here occurs often as a way to instruct listeners about the true relationship between means and ends, actions and their consequences. ${ }^{5}$ Here, the antecedent clause of the conditional is an expression of desire (if you want the children), indicating the desired or intended ends that can be achieved by the means specified in the consequent clause (then you can follow this way of doing things).

The evangelist questions the relationship between people's actions and their intentions, their means to their ends: are people ignoring the construction work on the school and tending to their pandanus harvest because they want their children to grow up to wash the clothes of other people? This is, of course, no one's intention. By emphasizing 
that people's actions (tending to their pandanus) are out of line with their intentions (keeping their children from growing up to be others' servants), the evangelist casts doubt on people's self-determination: are people willfully "following their hearts" by tending to their pandanus garden instead of thinking of their community, as many critics were charging? According to the evangelist, people are in fact inadvertently acting against their own will and ceding their self-determination by ignoring the construction work at the school.

The evangelist's remarks illustrate a common rhetorical device in Yopno political oratory, one that consists of redescribing listeners' actions and thereby highlighting the divergence between listeners' understanding of their own actions (i.e., what they think they are doing) and the reality of what they are doing. By providing an alternative description-a fuller or more accurate representation meant to expand and correct people's understanding of their own actions-speakers suggest that people do not have the knowledge to act as self-determining agents.

By sowing doubt about listeners' understanding of the consequences of their own actions, orators establish listening as a means of reclaiming self-determination. In part, this rhetoric of expert instruction is prevalent precisely because it provides speakers a way of commanding the attention of listeners who do not readily take instructions from others. But purported experts are not the only source of doubts about the true nature of actions. Failures to attain hoped-for outcomes in all manner of activities lead community members to question their understanding of how reality works. And a widespread sense that other agents play a role in shaping a person's future-and that they are responsible for the failures of a person's efforts-makes knowledge of these often-obscure others essential for a person's projects of self-making.

\section{Expertise and the obscurity of action}

In a characteristic Melanesian view of personhood, according to Marilyn Strathern (1988), there is no singular, unique self at the core of each person. Rather, the person is a "microcosm of relations," their body "composed of the specific historical actions of social others: what people have or have not done to or for one" (1988, 131-32; see also Biersack 1982; Foster 1990; Thomas 1991). Persons are formed by and dependent on a variety of others-one's person and even one's body are radically permeable insofar as they are constituted by the acts of others. Understanding oneself and fashioning one's future, then, involve not a deeper understanding of who one is at the core of one's being - that is, as an authentic self (Taylor 1991) — nor an effort to master oneself. Rather, such efforts involve better understanding the actions of the various agents that formed the self and shape who one becomes-agents such as mothers and fathers, exchange partners, fellow villagers, spirits, the Christian god, and conservation NGOs.

But in Yopno communities, knowledge of these others-of how they have constituted one's person and of how one can influence them to act in order to refashion oneself-is unevenly distributed (this unevenness is a common basis of stratification and differentiation in Melanesia; see, e.g., Lawrence 1965; Leach 2012; Lindstrom 1984). Before Christianity arrived, the men's cult partitioned communities into the initiated (adult men) and the uninitiated (women and children) on the basis of their knowledge of powerful esoterica (Kocher Schmid 1991). Today, many specialized roles in villages revolve around the esoteric knowledge disseminated in schools and churches-teachers and pastors, school-board members and congregation leaders.

People seek out specialized knowledge from clan elders, church leaders, and teachers because so much of the context of their lives and the agents who influence them are invisible to untrained human perception-witchcraft and sorcery, curses that afflict people because of ancestors' misdeeds, the spirits that inhabit the forest, the concealed emotions and thoughts of covillagers, long and often forgotten histories of exchanges that establish credits and debts.

In 2014, I joined a Christian spiritual leader, Peter, on a visit to two women who had asked to speak with him. Now in his 50s, Peter was in the late 1980s one of the young Turks whom the Nian village headmen designated as a church leader after he returned from work on coastal plantations, where he and his companions had developed a deeper knowledge of Christianity. Kauso, the more vocal of the two women he was visiting, was married and approaching middle age. She had given birth to a daughter several years before but had no sons, a growing concern for her and her husband, who was hoping for a male heir. Both Kauso and her cousin, who also had no sons, were trying to figure out why they seemingly could not produce male offspring. They had requested that Peter come and identify the reason for them. Kauso begins by expressing her confusion:

Our lives are messed up.

We wonder, "Is it because we did this? Is it because of that?"

Our lives are messed up.

Is it because of this or something else that they are messed up?

We have wondered about this and now we are going to talk about it.

[...] 
My own mother and father did not get married in the right way.

People didn't arrange their marriage.

They married in a thieving way [i.e., without the proper arrangements and bridewealth transactions].

Are our lives messed up because of that?

Is it because of that that we have problems?

We wonder about that sort of thing, and we asked you to come.

You have come, so you can listen to us talk and end our problems.

For that we asked you to come.

Kauso plays up her own confusion here: is she cursed because her parents were married without the payment of bridewealth, or is there some other cause? There are multiple possible causes of their troubles, and the work of experts like Peter is to identify the actual one. Kauso and her cousin suggest two likely causes: that their parents' marriages were not arranged but the product of their own desires, or that their parents were members of each other's partner clan (Y: gapma) and thus improper marriage partners.

After hearing their suggestions, Peter declared that the source of their problems was the second one. Gapma regard one another reciprocally as a source of blessings-as each other's "gods" - and there is a strong prohibition on marriage among them. Because Kauso's mother violated this prohibition, treating her "god" with disrespect by marrying him, her gapma gave her no male offspring. And this inability to give birth to sons has continued to curse the family in the next generation too. In Peter's words,

The man who should guide them [i.e., their gapma], the one who should make decisions [... ] didn't give a boy to her [i.e., Kauso's mother].

"You yourself have blocked the road for a boy, so I won't give you a boy. I give you only girls."

They [i.e., their gapmas] said this, and there aren't plenty [of children], just one.

$[\ldots]$

We'll blame evil spirits and all sorts of things, but it's not that.

Because the gapma plate was turned [i.e., gapmas married each other], these problems truly come.

What the spiritual expert provides access to here is the perspective of the gapma, speaking in their voice (this expression is a curse [Y: jobit] that is especially powerful coming from one's "god”). A person's body-its reproductive capacities-is constituted by the actions of others, who themselves are reacting to the affected person's own actions (or their kin's actions) in a back-and-forth, reciprocal exchange that requires expertise to untangle.

To act effectively, then, people must understand the history of actions in which they are entangled-and, particularly, they must recognize the perspective of others who have affected them in the past or will affect them in the future. But the dense entanglement of relations, the invisibility of some actors and their actions, and the long histories of give-and-take all make it difficult to gain hold of the correct description of the context in which they are acting and, hence, of their own actions. Listening, then, to the insight provided by experts provides a way to gain control of one's actions and one's future.

New actors - the Christian god, missionaries, government representatives, and a US-based NGO - have only added to people's sense that their self-determination is at risk. But this is not, for the most part, because people fear the coercive power of the Papua New Guinean state or other organizations engaging with people in the Yopno valley. As others have noted, Papua New Guinea "hardly qualifies as a 'strong state,' capable of coercing its citizensubjects through persuasion and/or violence” (Foster 2002, 4; Douglas 2000). Moreover, people in the valley have not encountered much of the coercive domination that has characterized the colonial and postcolonial experience in much of the world. There is rather some nostalgia for the colonial era and a sense that people in the valley missed out on the opportunities for development that colonialism afforded other parts of Papua New Guinea.

People have, for instance, welcomed the arrival of a US-based conservation NGO, whose aim is to protect an endangered species of tree kangaroo. This organization provides funding to educate locals to become teachers and to run medical posts and a pilot kindergarten program, and plans to train conservation enforcement officers and to establish courts to administer the YUS [Yopno-UruwaSom] Conservation Area, which it helped to establish in the Yopno and neighboring valleys. The statement in the title of Paige West's (2006) account of conservation efforts in another region of Papua New Guinea is one I've heard expressed approvingly by many people in the Yopno valley: "Conservation is our government now." Given the lack of services provided by the Papua New Guinean state, people see the conservation NGO as a potentially valuable partner.

In seeking to determine their own future, an effort that often involves trying to find a means to achieve the "development" they hope for, people in the Yopno valley see as indispensable relations of exchange and interdependence with actors and institutions from outside the valley (a common theme in New Guinea; Barker 2004; Kirsch 2006; Street 2014). People complain that they are poor and backward because the state and other organizations are uninvolved in their lives. In this view, self-determination-the capacity to shape one's future-is not the same as autonomy. 
Table 1. Franklin, a field assistant for a conservation NGO working in Papua New Guinea, seeks to clarify the effects of the NGO's work on nature spirits (netsa). He contrasts his own perspective on actions (italicized in the transcript) and their consequences (underlined) with the perspective held by many of his listeners

\begin{tabular}{|c|c|}
\hline $\begin{array}{l}\text { Whatever you thought before, for instance that they are going around visiting the spirits who } \\
\text { live on our land. }\end{array}$ & Listeners' perspective \\
\hline $\begin{array}{l}\text { I am a true Yopno person. I'm telling you directly, none. I have not seen one spirit in the } \\
\text { forest. They don't come to me. } \\
\text { But they celebrate. When I walk around, they do not worry about all sorts of enemies coming } \\
\text { into the forest. There are all sorts of enemies who are coming here. We don't know how to } \\
\text { control them. } \\
\text { When we don't know how to manage things, all of this forest, land, they are anxious and worry. } \\
\text { When you conserve them, then they are at peace, they feel calm. }\end{array}$ & Speaker's perspective \\
\hline $\begin{array}{l}\text { And they see you, this proprietor of the forest and ground or YUS man, they see you as their } \\
\text { powerful king. That's how netsa now see you all [...] }\end{array}$ & Netsa's perspective \\
\hline $\begin{array}{l}\text { So now, a Yopno child, I myself, say: it's a false account. False thinking. Cargo cult thinking. } \\
\text { It goes against this Garden of Eden we want to walk around in. }\end{array}$ & $\begin{array}{l}\text { Speaker's perspective on listeners' } \\
\text { perspective }\end{array}$ \\
\hline If we conserve it, we go back to Genesis. & Speaker's perspective \\
\hline So watch out. God's Word also will indict you. & $\begin{array}{l}\text { God's perspective on listeners' } \\
\text { perspective and actions }\end{array}$ \\
\hline
\end{tabular}

At the same time, people worry that they do not fully understand the nature of these relationships. Owing to the remoteness of the region and the fact that the colonial administration prioritized economic development in more accessible regions of Papua New Guinea, the first colonial officers arrived in the Yopno valley only in the late 1930s, and the first government school was built only just before independence, in 1975. Many locals see this as a source of their "ignorance" and "backwardness" compared to the rest of Papua New Guinea and the world at large.

The sense that reality is opaque crops up in many facets of life in the Yopno valley, such as when people interact with forest spirits, resolve ancestral curses, engage in environmental conservation efforts, and build schools to ensure that children are prepared for the future. This opacity motivates people to value not only expertise in Yopno political life but also the practice of listening to those who provide it.

\section{Provisioning expertise, representing reality}

The focus on listening and the self-determination of the listener in the communication of expertise goes hand in hand with a focus on the accuracy of expert representations of reality. After all, the value of expert speech for the listener lies in gaining hold of a truer and more comprehensive understanding of reality. Indeed, in their redescriptions of action, experts highlight this value of expert speech as the fundamental difference between their own account of how reality works and that of their listeners. In the following example, a conservation worker presents two contrasting perspectives on nature spirits (TP: netsa) and their relationship to the conservation efforts. Though the term netsa is cognate with the English word nature, it has a distinct meaning from its English counterpart, one that lies at the heart of a "working misunderstanding" between residents of the Yopno valley and the conservation NGO, a misunderstanding that is at times productive and at other times confounding. Netsa denotes not only "forest," "animals," "streams," and the like but also the spirits that live in and control them.

Many in the Yopno valley understand the efforts of the conservation NGO to protect their nature-the forest, animals, and streams of people in the Yopno valley-as an effort to protect their netsa. Supporters of the conservation work appreciate the NGO's efforts to protect the spirits of the forest-people's source of power and a potential source of wealth-from others, whether other clans or mining companies. At times, though, the conservation NGO can appear too interested in Yopno netsa, leading people to wonder whether the NGO is in fact there to steal this source of power and wealth.

In 2014 the NGO hosted a workshop to teach people in Nian village how to grow and prepare coffee for the US market. Much of the talk, aside from the technical instruction, focused on the benefits the NGO was providing to people in the valley. Franklin, a local who works as a field assistant for the NGO tracking tree kangaroos in the forest, also sought to clarify for his audience the effects of the conservation work on netsa. In the extract of his speech presented in Table 1, he contrasts his own perspective on actions (italicized in the transcript) and their consequences (underlined) with the perspective held by many of his listeners.

In his speech, Franklin presents multiple perspectives on the conservation project. Though I have called them all "perspectives," Franklin does not present them as different but equally valid. Rather, he contrasts his own perspective with that of his listeners, which he devalues 
as "false," a kind of "cargo-cult thinking." ${ }^{2}$ Listeners' mistaken understanding of reality leads them to act in ways they do not understand, with consequences they do not intend: they endanger the Garden of Eden that they want to create, and they bring down the wrath of God on themselves. They make their netsa feel pain and worry. To this, Franklin juxtaposes his own expert account, underwritten by his close involvement with the NGO, his long-term work in the forest, and his local origins - an expert account partly composed of a series of conditional sentences linking antecedent actions to their consequents. What really happens, according to Franklin, is that when you conserve your land, these spirits are thankful.

Set alongside perspectives beset by ignorance or shortsightedness, the speaker frames his own perspective as a truer and fuller account of reality, one that can accurately and fully represent the perspectives of other important actors (e.g., netsa, the Christian god). Franklin's speech contains multiple "voices," in Bakhtin's (1981) sense of the term: linguistic expressions of distinctive perspectives, which members of a speech community often associate with social identities (on voice, see also Harkness 2014; Keane 1999; on "footing" and "stance," two closely related concepts, see Du Bois 2007; Goffman 1979).

Though the notion of voice in the democratic model of self-sovereignty discussed earlier is not the same as the Bakhtinian notion of voice, they are linked within the politics of voice. In a democratic model of political legitimacy, speech and other forms of communication are the means through which political subjects act as sovereigns. For speech to serve as a vehicle of self-sovereignty, it must serve as an expression of one's self-a Bakhtinian voice that expresses one's "preferences, interests, identities, values" (Urbinati and Warren 2008, 396). In other words, the democratic emphasis placed on self-sovereignty accentuates the role of political speech as a mode of expressing the speaker's self, indicating his or her distinctive values, interests, experiences, and perspectives.

Where the politics of voice emphasizes the expression of the speaker's self as a mode of securing self-determination, the Yopno communication of expertise emphasizes the value of more accurate representations of reality as a mode of fostering the self-determination of listeners. (Of course, this does not mean that experts' representations are necessarily true and comprehensive, only that participants assess these representations for their accuracy.) The self-determination of the listener hinges on speech not as an expression of the subjectivity of the speaker but as an accurate and fuller description of reality. The "use value" of this speech for listeners lies in providing the knowledge they need to control their future.
Table 2. Mannu, a community leader in Ganggalut village, elucidates the relationship between support for a public conservation celebration and the benefits offered to community members by the NGO organizing the celebration. He stresses people's ignorance of the consequences of their actions, contrasting his village's perspective on actions (in italics) and their consequences (underlined) with the views of other villages

\begin{tabular}{|c|c|}
\hline $\begin{array}{l}\text { Our eyes don't see these things [the } \\
\text { benefits of helping with conservation } \\
\text { work]. } \\
\text { So we think, "What sort of thing is this } \\
\text { we will be doing?" While we think that } \\
\text { way and are doubtful, }\end{array}$ & Listeners' perspective \\
\hline $\begin{array}{l}\text { because other villages have already } \\
\text { seen it, because they have already } \\
\text { seen the fruits of this work, they do } \\
\text { the work. }\end{array}$ & $\begin{array}{c}\text { Other village's } \\
\text { perspective }\end{array}$ \\
\hline $\begin{array}{l}\text { You do the work, and because of that, } \\
\text { later, you will see the benefit. } \\
\text { In a short time, you will see it and what } \\
\text { will you think then? It's because you } \\
\text { do the work now, that's what we're } \\
\text { saying. }\end{array}$ & Speaker's perspective \\
\hline
\end{tabular}

\section{Learning to listen: Truth, deception, and the need to listen well}

Though speakers present their expertise as a benefit to the listener, experts also have an interest in directing people to act in particular ways. Indeed, people in the Yopno valley are attuned to the possibility that purported experts are deceiving and manipulating them. Deception and manipulation are a theme running through local historical tales, anecdotes, and people's observations about presentday experts (a preoccupation elsewhere in Melanesia as well; see, e.g., Rumsey 2013; Weiner 1983). Anticipating the possibility of deceit, listeners are careful to listen well and evaluate (Y: silip $a$-) the speech of experts, lest the experts deceive and manipulate them into becoming their "slaves."

In 2009, when people were preparing to host a celebration marking the establishment of the YUS Conservation Area, I was residing alternately in the villages of Ganggalut and Weskokop. The factions I was living with in both villages came to quite different understandings of their involvement in the conservation efforts. In Ganggalut, community leaders urged support for the celebration-preparing houses, gathering firewood and food for guests, preparing the grounds for the celebration-as a way to secure benefits from the NGO. When most of the village failed on several occasions to show up on days allotted for this work, community leaders clarified the consequences of their acts for them.

In the transcript in Table 2, Mannu echoes the contributions of several women and men speaking at a community meeting and elucidates the relationship between 
the celebration and the expected benefits. Throughout, he stresses people's ignorance of the consequences of their actions, contrasting Ganggalut's perspective on actions (in italics) and their consequences (underlined) with the views of other villages.

The discussion goes on at length. As another man says later, "We speak until our mouths hurt for the benefit of everyone." The idea is that helping people to see the nature of their actions will enable them to gain access to benefits that they want.

The statement that this advice is provided "for the benefit of everyone" is a rejoinder to those who feel that all this talk is not, in fact, for their benefit. Some recipients of advice like this dismiss it as an attempt by the speaker to deceive them into doing work that the speaker wants done. If a premise of the provisioning of expertise is that reality is opaque, then the veracity of what experts say is itself opaque.

At roughly the same time as the discussion in Ganggalut, I attended a similar meeting in Weskokop, where discussion of the conservation work took another direction. People argued that the conservation celebration would not bring them benefits. It was, they argued, the educational accomplishments of their children that would earn them scholarships from the NGO. They asserted that those organizing the celebration were deceiving them. It was, they said, only the organizers themselves and their well-educated children who would receive benefits.

In the following excerpt, a young man named Monji gave a bravura performance in which he summarized much of what his elders had been saying. Note how the discussion centers on evaluating the talk of the celebration's organizers:

Monji: This work [for the conservation celebration] that you are going to do, what will you get out of it? [...] It wouldn't be good if we work hard and other people receive the benefit [i.e., scholarships for their children to attend teachers' college]. I'm telling you, we are really their [other communities'] laborers. [...] Their representatives will speak to you, and you are excited and clap about it. Don't just cheer. You don't want to cheer and strengthen their lies. You see me there at the meetings. If I feel it's not OK, I don't laugh and clap my hands. When the talk I hear is not satisfactory in my mind, when I hear something questionable, and I think it's not OK, I just sit there. You are excited for no reason. This has become your way of doing things. Stop it and clarify your thinking. You think, "If we talk like that, they will like us." [...] I don't have pigs and money, but my thinking is excellent! [laughter] [ ... ] Weskokop, they deceive you with kind words. They call you their slaves and pat you on the back and you keep doing it [laughter].
Nanda: [...] All the people from the other side [i.e., the celebration organizers] have received the benefit, and they give you orders, you see. [...] They have already received the benefit. They tell you to clean up their village. If you want to get the benefit, then that's the place to get it [indicating the preschool; Nanda and Monji claim that it is well-educated children who will get the scholarships to the teachers college].

Monji: [ . . . ] At Teptep and here too, I have been watching them. When I want to speak, they ignore me and call on someone else. There's a reason they do this. I have seen and speak out about their secrets. [...]

Esal: You are bringing this secret talk out into the light, so I'm laughing at you. ${ }^{7}$

People's propensity for deception serves only to reinforce the premise that underlies expert communicationsnamely, that reality is opaque to nonexperts. One must therefore carefully evaluate the speech of others, lest one end up being another's laborer (see Slotta 2015 for the important role that "evaluation" plays as part of listening in Yopno politics). For Monji and Nanda, it is not enough just to listen; one must listen well. Self-styled experts like them purport to listen better to the speech of others and share the fruits of their careful evaluation, but their evaluation too is subject to further evaluation by their listeners. In a tension central to the Yopno provisioning of expertise, people must listen to expert representations of reality to come to understand the true nature of the contexts in which they act; at the same time, they must carefully evaluate these representations to sort out truth from deception. ${ }^{8}$

Worries about losing control of the future push people to schools and churches in order to listen and gain the understanding they need to secure control of their future. From a perspective located within more familiar political formations - the politics of voice, the politics of recognition-it is ironic that Yopno flock to these "foreign" institutions and seek out "foreign" knowledge in an effort to advance their self-determination. But from a perspective embedded in the logic of the Yopno communication of expertise and the political and epistemological conditions that foster it, there is nothing ironic about it at all.

\section{Conclusion: From the listener's point of view}

I have considered here how political arrangements and ideologies spotlight different components of communicative encounters (speakers, listeners) and vest significance in different communicative functions (self-expression, representation). In the politics of voice, the significance of speaking as a source of power and self-determination is fostered by a democratic model of political legitimacy, one in which state power is legitimized as an exercise 
of citizens' self-sovereignty through the effective expression of speakers' values, interests, and points of view. In other words, citizen-speakers express their selves as a voice that the state "hears" and reflects in law and policy.

Throughout this article, I have used the politics of voice as a foil for elucidating the Yopno provisioning of expertise. The latter is a mode of political communication that spotlights the value of accurate and comprehensive representations of reality as a means of fostering the self-determination of listeners. That being said, the speech events I have discussed here can also be taken as evidence of the power that expertise vests in speakers: after all, it is a commonplace among people in the Yopno valley that purported expertise is used to manipulate listeners and further the interests of so-called experts. Such a perspective accords with postpositivist accounts of knowledge production and circulation, accounts that stress the interest-, value-, and perspective-laden nature of representations of reality (Bloor 1976; Foucault 1972; Haraway 1988; Kuhn 1970; Latour and Woolgar 1986; Shapin 1994). Concerned with the production and promulgation of knowledge, scholars working within this paradigm emphasize that representations do not merely reflect reality but constitute it. Much of this work speaks to the importance of classification and representation more broadly as key modes of establishing and exercising power over subjects, particularly on the part of states and bureaucratic institutions that have at their disposal a variety of additional means of coercion and regimentation (Armstrong 1983; Dean 1991; Ferguson 1994; Hacking 1995; Mitchell 1988; Rabinow 1995; Rose 1998).

In the context of Western liberal democracies, wherein the authority of experts sits uneasily alongside the sovereignty of "the people," such social-constructivist accounts of knowledge production have made it difficult to legitimize the authority of experts (Bohman 1996; Fischer 2000; Jasanoff 2009; Turner 2003). After all, "if it is no longer clear that scientists and technologists have special access to the truth, why should their advice be specially valued?" (Collins and Evans 2002, 236). As the boundary breaks down between "facts," on the one hand, and "values" and "interests," on the other (Putnam 2002), it becomes harder to distinguish expertise and voice as distinct types of legitimate authority appropriate to separate domains (cf. Weber 1946). ${ }^{9}$ The expert's "facts" and "truth" appear to be just another perspective, and "expertise" appears to be a mask that lends an aura of disinterestedness and value neutrality to what is, in fact, the voice of the so-called expert.

But as the provisioning of expertise in Yopno politics highlights, other parties besides the producers and promulgators of knowledge have an interest in expertise as well. The circulation of expertise serves multiple functions simultaneously: expert speakers do indeed reveal their knowledge in an effort to gain influence and status in Yopno communities (Slotta 2014), but listeners too have an interest in such representations as a way to better understand the workings of reality. Without the interest of listeners in gaining access to knowledge, no one would heed the words of experts in this context. Though there is certainly tension among the differing interests of speakers and listeners (evident in concerns about deception), the communication of expertise is not necessarily a zero-sum game, in which it is either speakers or listeners whose interests are served.

The multiple functions of expertise in Yopno political discourse, then, push back against a view of communication that reduces speech to merely the expression of a speaker's interests, values, and perspectives. An earlier anthropology all too often divorced representations from their social life in communicative practices (e.g., structuralism [Lévi-Strauss 1966] and ethnoscience [Frake 1964]), looking to language abstracted from its use in context for signs of speakers' cultural concepts and values, their subjectivity and interests. In contrast, poststructuralist approaches have shown how representations are produced and promulgated in discursive practice, shedding light on how representations are partial, power-laden, and bound to the subject positions of those who produce them. The communication of expertise in Yopno politics pushes us to expand on such an approach by drawing attention to the role of listeners and listening as another facet of the political work of representations. Concerns about listening that feature in Yopno politics do not render an analysis centered on voice unnecessary or fruitless. But they do urge a more encompassing view of representational practice attentive to the multiple functions and components of communicative events: to the perspective of listeners as well as speakers, to the utility of representations for their recipients as well as their promulgators. Moreover, the emphasis on listening in Yopno politics urges further consideration of the particular political and epistemological conditions-among others-that foster more familiar concerns about speaking and accentuate the value of speech as (1) a source of power and self-determination, (2) an expression of speakers' subjectivities, and (3) a mode of constituting reality in the service of speakers' interests.

\section{Notes}

Acknowledgments. As always, I am grateful to the many people in the Yopno valley who have supported my research in various ways. The research for this article was supported by the FulbrightHayes Program, the Wenner-Gren Foundation, and the Endangered Languages Documentation Programme. I received helpful feedback on earlier drafts from audiences at Binghamton University, State University of New York; the University of Texas at Austin; 
the University of Virginia; and the University of California, Los Angeles. For insightful questions and comments that have markedly improved the final product, I must thank Kamran Ali, Luke Fleming, Ilana Gershon, Courtney Handman, John Hartigan, China Scherz, Pauline Strong, and Anthony Webster, as well as Niko Besnier and four anonymous reviewers.

1. In contrast to the democratic emphasis on the sovereignty of "the people," republican traditions have stressed other grounds for the legitimacy of representative government. These often include "aristocratic" elements that are at odds with the democratic model of political legitimacy that I focus on here. On this point, I thank a reviewer for directing me to Bernard Manin's (1997) work.

2. Throughout this article, I use the abbreviation $Y$ to mark translations in the Yopno language and $T P$ to mark those in Tok Pisin.

3. All personal names in this article are pseudonyms. The speeches and conversations reported throughout have been translated from Yopno and Tok Pisin. Audio recordings and transcripts of these materials in the original languages, with interlinear glosses, are available on the American Ethnologist website (refer to the link associated with this article). Aside from the linguistic materials, the fuller picture of these communicative events afforded by the recordings is also illuminating. For instance, the background noise in the recording of Topa's speech in the village market-the murmur of other conversations, the grunts of pigs-makes palpable the sense that nobody, in fact, is listening.

4. In the context of village politics, the most notable exceptions are (1) curses (Y: jobit) that bring misfortune on their targets and that are a quintessential model of the power of words and (2) threats of witchcraft and sorcery by leaders who, in the past, used these to ensure that people complied with their orders. In what is widely held to be a more enlightened Christian era, both are considered inappropriate to contemporary political discourse.

5. An overview of Yopno and Tok Pisin conditional constructions is available on the American Ethnologist website: http:// americanethnologist.org/read/journal/volume-44-issue-2-may2017 /slotta.

6. There is now a sizable literature on "the opacity of mind" in the Pacific (Duranti 2015; Hollan and Throop 2011; Rumsey and Robbins 2008). This work explores the relative lack of talk about other people's intentions, thoughts, and desires found in the region. In most of the examples discussed here, however, it is evident that the discussion of others' thoughts and desires is a central element of Yopno political oratory.

7. Monji's forceful speech, which largely echoed what his elder Nanda had said earlier, gave rise to much laughter. It was unusual for a young man like Monji to speak like this, and his performance, while serious in its subject matter, was delivered with a wink that made it quite humorous.

8. The circulation of knowledge in Yopno communities is closely bound up with kinship relations, as one reviewer suggested. In particular, concerns about deception lead people to put their trust in the representations of those with whom they have ongoing feelings of mutual interest and long-term obligation. So, for instance, villages, clans, and even extended families try to ensure that each have experts of their own. Noting that "it won't be good if others use their knowledge to deceive us," Monji asks later in this meeting: "Have you educated someone among yourselves who is devoted to you and will look after your interests?" Kinship relations lend support to the veracity of representations and more generally give rise to trust that knowledge will be deployed in one's interest.

9. My thanks to China Scherz for drawing my attention to the resemblances between Weber's account of the proper relationship between science and politics, and my description of the Yopno provisioning of expertise.

\section{References}

Armstrong, David. 1983. Political Anatomy of the Body: Medical Knowledge in Britain in the Twentieth Century. Cambridge: Cambridge University Press.

Bakhtin, M. M. 1981. "Discourse in the Novel." In The Dialogic Imagination: Four Essays, edited by Michael Holquist, translated by Michael Holquist and Caryl Emerson, 259-422. Austin: University of Texas Press. First published 1975.

Barker, John. 2004. "Between Heaven and Earth: Missionaries, Environmentalists, and the Maisin." In Globalization and Culture Change in the Pacific Islands, edited by Victoria S. Lockwood, 439-59. Upper Saddle River, NJ: Prentice Hall.

Biersack, Aletta. 1982. "Ginger Gardens for the Ginger Woman: Rites and Passages in a Melanesian Society." Man 17 (2): 239-58.

Bloor, David. 1976. Knowledge and Social Imagery. Chicago: University of Chicago Press.

Bohman, James. 1996. Public Deliberation: Pluralism, Complexity, and Democracy. Cambridge, MA: MIT Press.

Brison, Karen J. 1989. "All Talk and No Action? Saying and Doing in Kwanga Meetings.” Ethnology 28 (2): 97-115.

Butler, Judith. 1997. Excitable Speech: A Politics of the Performative. New York: Routledge.

Chambers, Simone. 2003. "Deliberative Democratic Theory." Annual Review of Political Science 6:307-26.

Collins, Harry M., and Robert Evans. 2002. "The Third Wave of Science Studies: Studies of Expertise and Experience.” Social Studies of Science 32 (2): 235-96.

Dean, Mitchell. 1991. The Constitution of Poverty: Toward a Genealogy of Liberal Governance. London: Routledge.

Douglas, Bronwen. 2000. "Weak States and Other Nationalisms: Emerging Melanesian Paradigms." State, Society, and Governance in Melanesia Discussion Paper no. 00/3, Australian National University, Canberra.

Du Bois, John W. 2007. “The Stance Triangle.” In Stancetaking in Discourse: Subjectivity, Evaluation, Interaction, edited by Robert Englebretson, 139-82. Amsterdam: John Benjamins.

Duranti, Alessandro. 2015. The Anthropology of Intentions: Language in a World of Others. Cambridge: Cambridge University Press.

Ferguson, James. 1994. The Anti-politics Machine: "Development," Depoliticization, and Bureaucratic Power in Lesotho. Minneapolis: University of Minnesota Press.

Fischer, Frank. 2000. Citizens, Experts, and the Environment: The Politics of Local Knowledge. Durham, NC: Duke University Press.

Foster, Robert J. 1990. "Nurture and Force-Feeding: Mortuary Feasting and the Construction of Collective Individuals in a New Ireland Society." American Ethnologist 17 (3): 431-48.

2002. Materializing the Nation: Commodities, Consumption, and Media in Papua New Guinea. Bloomington: Indiana University Press.

Foucault, Michel. 1972. The Archaeology of Knowledge. Translated by A. M. Sheridan Smith. New York: Pantheon. First published 1969.

Frake, Charles O. 1964. "Notes on Queries in Ethnography." American Anthropologist 66 (3): 132-45.

Goffman, Erving. 1979. "Footing." Semiotica 25 (1-2): 1-30.

Habermas, Jürgen. 1996. Between Facts and Norms: Contributions to a Discourse Theory of Law and Democracy. Translated by William Rehg. Cambridge, MA: MIT Press. First published 1969.

Hacking, Ian. 1995. Rewriting the Soul: Multiple Personality and the Sciences of Memory. Princeton, NJ: Princeton University Press. 
Haraway, Donna. 1988. "Situated Knowledges: The Science Question in Feminism and the Privilege of Partial Perspective." Feminist Studies 14 (3): 575-99.

Harkness, Nicholas. 2014. Songs of Seoul: An Ethnography of Voice and Voicing in Christian South Korea. Berkeley: University of California Press.

Hollan, Douglas W., and C. Jason Throop. 2011. The Anthropology of Empathy: Experiencing the Lives of Others in Pacific Societies. New York: Berghahn.

Jasanoff, Sheila. 2009. The Fifth Branch: Science Advisers as Policymakers. Cambridge, MA: Harvard University Press.

Keane, Webb. 1999. "Voice." Journal of Linguistic Anthropology 9 (1-2): 271-73.

Keck, Verena. 2005. Social Discord and Bodily Disorders: Healing among the Yupno in Papua New Guinea. Durham, NC: Carolina Academic.

Kirsch, Stuart. 2006. Reverse Anthropology: Indigenous Analysis of Social and Environmental Relations in New Guinea. Stanford, CA: Stanford University Press.

Kocher Schmid, Christin. 1991. Of People and Plants: A Botanical Ethnography of Nokopo Village, Madang and Morobe Provinces, Papua New Guinea. Basel: Wepf.

Kuhn, Thomas S. 1970. "Logic of Discovery or Psychology of Research?" In Criticism and the Growth of Knowledge, edited by Imre Lakatos and Alan Musgrave, 1-23. Cambridge: Cambridge University Press.

Kulick, Don. 1992. Language Shift and Cultural Reproduction: Socialization, Self and Syncretism in a Papua New Guinean Village. Cambridge: Cambridge University Press.

Kunreuther, Laura. 2014. Voicing Subjects: Public Intimacy and Mediation in Kathmandu. Berkeley: University of California Press.

Latour, Bruno, and Steve Woolgar. 1986. Laboratory of Life: The Construction of Scientific Facts. Princeton, NJ: Princeton University Press.

Lawrence, Peter. 1965. "The Ngaing of the Rai Coast." In Gods, Ghosts and Men: Some Religions of Australian New Guinea, edited by Peter Lawrence and M. J. Meggitt, 198-223. Oxford: Oxford University Press.

Leach, James. 2011. “'Twenty Toea Has No Power Now’: Property, Customary Tenure, and Pressure on Land Near the Ramu Nickel Project Area, Madang, Papua New Guinea." Pacific Studies 34 (23): 295-322.

. 2012. "Leaving the Magic Out: Knowledge and Effect in Different Places." Anthropological Forum 22 (3): 251-70.

Lévi-Strauss, Claude. 1966. The Savage Mind. Chicago: University of Chicago Press. First published 1962.

Lindstrom, Lamont. 1984. "Doctor, Lawyer, Wise Man, Priest: BigMen and Knowledge in Melanesia." Man 19 (2): 291-309.

Ludden, David. 2002. "Introduction: A Brief History of Subalternity.” In Reading Subaltern Studies: Critical History, Contested Meaning and the Globalization of South Asia, edited by David Ludden, 1-39. London: Anthem.

Manin, Bernard. 1997. The Principles of Representative Government. Cambridge: Cambridge University Press.

Mansbridge, Jane. 1990. "Feminism and Democracy." American Prospect, March, 127-36.

McLeod, Christopher, dir. 2013. Profit and Loss. Berkeley, CA: Sacred Land Film Project. DVD.

Mitchell, Timothy. 1988. Colonising Egypt. Cambridge: Cambridge University Press.

Mouffe, Chantal. 2000. The Democratic Paradox. London: Verso.

Myers, Fred R. 1986. "Reflections on a Meeting: Structure, Language, and the Polity in a Small-Scale Society." American Ethnologist 13 (3): 430-47.
Putnam, Hilary. 2002. "The Collapse of the Fact/Value Dichotomy" and Other Essays. Cambridge, MA: Harvard University Press.

Rabinow, Paul. 1995. French Modern: Norms and Forms of the Social Environment. Chicago: University of Chicago Press.

Rakow, Lana F., and Laura A. Wackwitz. 2004. "Voice in Feminist Communication Theory." In Feminist Communication Theory, edited by Lana F. Rakow and Laura A. Wackwitz, 93-110. London: Sage.

Robbins, Joel. 2001. "God Is Nothing but Talk: Modernity, Language, and Prayer in a Papua New Guinea Society." American Anthropologist 103 (4): 901-12.

Rodman, William L. 1991. "When Questions Are Answers: The Message of Anthropology, According to the People of Ambae." American Anthropologist 93 (2): 421-34.

Rose, Nikolas. 1998. Inventing Our Selves: Psychiatry, Power and Personhood. Cambridge: Cambridge University Press.

Rousseau, Jean-Jacques. 1987. "On the Social Contract.” In The Basic Political Writings, translated by D. A. Cress, 139-227. Indianapolis: Hackett. First published 1762.

Rumsey, Alan. 2013. "Intersubjectivity, Deception and the 'Opacity of Other Minds': Perspectives from Highland New Guinea and Beyond." Language and Communication 33 (3): 326-43.

Rumsey, Alan, and Joel Robbins, eds. 2008. "Anthropology and the Opacity of Other Minds." Special issue, Anthropological Quarterly 81 (2).

Schieffelin, Bambi B. 1990. The Give and Take of Everyday Life: Language Socialization of Kaluli Children. Cambridge: Cambridge University Press.

Shapin, Steven. 1994. A Social History of Truth: Civility and Science in Seventeenth-Century England. Chicago: University of Chicago Press.

Slotta, James. 2014. "Revelations of the World: Transnationalism and the Politics of Perception in Papua New Guinea." American Anthropologist 116 (3): 626-42.

. 2015. "The Perlocutionary Is Political: Listening as SelfDetermination in a Papua New Guinean Polity." Language in Society 44 (4): 525-52.

Spivak, Gayatri Chakravorty. 1988. "Can the Subaltern Speak?" In Marxism and the Interpretation of Culture, edited by Cary Nelson and Larry Grossberg, 271-313. Chicago: University of Illinois Press.

- 1989. "The New Historicism: Political Commitment and the Postmodern Critic." In The New Historicism, edited by H. Aram Veeser, 277-92. New York: Routledge.

Strathern, Marilyn. 1988. The Gender of the Gift: Problems with Women and Problems with Society in Melanesia. Berkeley: University of California Press.

Street, Alice. 2014. Biomedicine in an Unstable Place: Infrastructure and Personhood in a Papua New Guinean Hospital. Durham, NC: Duke University Press.

Taylor, Charles. 1991. The Ethics of Authenticity. Cambridge, MA: Harvard University Press.

Thomas, Nicholas. 1991. Entangled Objects: Exchange, Material Culture, and Colonialism in the Pacific. Cambridge, MA: Harvard University Press.

Turner, Stephen P. 2003. Liberal Democracy 3.0: Civil Society in an Age of Experts. London: Sage.

Urbinati, Nadia, and Mark E. Warren. 2008. "The Concept of Representation in Contemporary Democratic Theory." Annual Review of Political Science 11:387-412.

Wassmann, Jürg. 2016. The Gently Bowing Person: An Ideal among the Yupno in Papua New Guinea. Heidelberg: Universitätsverlag Winter. 
Weber, Max. 1946. "Science as a Vocation." In From Max Weber: Essays in Sociology, translated and edited by H. H. Gerth and C. Wright Mills, 129-56. New York: Oxford University Press. First Published in 1919.

Weiner, Annette B. 1983. "From Words to Objects to Magic: Hard Words and the Boundaries of Social Interaction." Man, New Series 18 (4): 690-709.

West, Paige. 2006. Conservation Is Our Government Now: The Politics of Ecology in Papua New Guinea. Durham, NC: Duke University Press.
Young, Iris Marion. 2000. Inclusion and Democracy. Oxford: Oxford University Press.

James Slotta

Department of Anthropology

University of Texas at Austin

2201 Speedway, Stop C3200

Austin, TX 78712

slottaj@gmail.com 